KuLTura- MeDia- TeoLogia

ISSN 2081-8971

$2017 \mathrm{nr} 28$, s. 33-49.

\title{
„Oni zawsze byli dziwni”. Analiza komplementarna powieści Richarda Yatesa "Revolutionary Road" i jej ekranizacji w reż. Sama Mendesa w świetle "Patologii codzienności" Ericha Fromma "They have been always strength". The complementary analyze of „Revolutionary Road "- Richard Yates 'novel and Sam Mendes adaptation in context of Erich Fromm „Patology of normalcy”.
}

\footnotetext{
STRESZCZENIE:

PRZEDMIOTEM TEGO ARTYKUŁU JeST ANALIZA KOMPLEMENTARNA POWIEŚCI RICHARDA YATESA

REVOLUTIONARY ROAD ORAZ JEJ EKRANIZACJI W REŻYSERII SAMA MENDESA. ANALIZA

KOMPLEMENTARNA ARTYKUEUJE I UWYPUKLA ODRĘBNOŚĆ SYSTEMÓW ZNAKOWYCH, JAKIMI POSŁUGUJĄ SIĘ LITERATURA I FILM, JENOCZEŚNIE ZWRACAJA UWAGE NA ZASADNICZO OSIĄGALNĄ I MOŻLIWĄ INTERSEMIOTYCZNĄ PRZEKEADALNOŚĆ NA POZIOMIEZNACZENIOWO- KULTUROWYM I TEN OBSZAR PODDAJE REFLEKSJI BADAWCZEJ. W FABUŁACH OBU DZIEE, ZARÓWNO LITERACKIEGO, JAK I FILMOWEGO, WYRÓŻNIONO KILKA KRĘGÓW TEMATYCZNYCH, KTÓRE ZOSTANĄ ZANALIZOWANE W NINIEJSZYM TEKŚCIE: ROZWÓJ RELACJI MAEŻEŃSKIEJ, WHEELEROWIE A RESZTA
}

\begin{abstract}
:
THE SUBJECT OF THIS ARTICLE IS TO ANALYZE COMPARATISTIC NOVEL BY RICHARD YATES PLOT REVOLUTIONARY ROAD AND ITS SCREENING OF DIRECTOR SAm Mendes. The Story OF this Distinguished SEVERAL THEMATIC CIRCLES: THE DEVELOPMENT OF THE MARRIAGE RELATIONSHIP, WHEELERS AND THE REST OF SOCIETY, "TABLE SCENE", THE HOUSE - A TRAP, THEME ROAD. THE ENTIRE ANALYSIS (BROKEN TO THE ABOVE PARAGRAPHS, EACH DEVOTED TO THEMATIC CIRCLES) AND WILL BE FOCUSED AROUND THE ISSUES AND MARRIAGE FAMILY AND SOCIO CUSTOM ENTANGLEMENT OF RELATIVITY CONCEPTS AND STANDARD / DEVIATION. THE METHODOLOGICAL BASIS OF THE ARTICLE ARE THE ARGUMENTS CONTAINED IN THE WORK OF ERICH FROMM PATHOLOGY OF NORMALCY. BOTH THE NOVEL AND ITS
\end{abstract}


SPOŁECZEŃSTWA, „SCENY STOŁOWE”, DOM - PUŁAPKA, MOTYW DROGI. CAŁA ANALIZA (ROZBITA NA WYŻEJ WYMIENIONE AKAPITY, POŚWIĘCONE POSZCZEGÓLNYM KRĘGOM TEMATYCZNYM) ZOGNISKOWANA ZAŚ BĘDZIE WOKÓŁ ZAGADNIENIA MAŁŻEŃSKO-RODZINNEGO I SPOŁECZNO-OBYCZAJOWEGO UWIKŁANIA JEDNOSTEK ORAZ RELATYWNOŚCI POJĘĆ NORMA/ ODSTĘPSTWO. PODSTAWE METODOLOGICZNĄ ARTYKULU STANOWIĄ teZY ZaWARTE W PRACY ERICha Fromma Patologia NORMALNOŚCI. ZARÓWNO POWIEŚĆ JAK I JEJ EKRANIZACJA RELACJONUJĄ WYDARZENIA MAJĄCE MIEJSCE W AMERYCE LAT 50., JEDNAK PROBLEMY W NIEJ PORUSZANE OKAZUJĄ SIĘ BYĆ UNIWERSALNYMI, A ZATEM WSPÓŁCZEŚNIE (DZISIAJ) RÓWNIEŻ AKTUALNYMI I GODNYMI REFLEKSJI.

\section{SŁOWA KLUCZOWE:}

REVOLUTIONARY ROAD, RELACJA MAEŻEŃSKA, PUELLA AETERNA, KONSUMPCJONIZM, NORMA PSYCHOLOGICZNA, PSYCHOPATIA, DOM - PUŁAPKA, RICHARD YATES, SAM MENDES, PATOLOGIA NORMALNOŚCI, ERICH Fromm
SCREENING REPORT THE EVENTS TAKING PLACE IN AMERICA '50s, BUT IT RAISED PROBLEMS TURN OUT TO BE UNIVERSAL, SO TODAY (TODAY) THE CURRENT AND WORTHY OF REFLECTION.

\section{KEYWORDS:}

REVOLUTIONARY ROAD, MARITAL RELATIONSHIP, PUELLA AETERNA, CONSUMERISM, STANDARD PSYCHOLOGICAL, PSYCHOPATHY, HOUSE - A TRAP, RICHARD YATES, SAM Mendes, PATHOLOGY OF NORMALCY, ERICH Fromm.

W ydaną w 1961 roku powieść Richarda Yatesa krytycy charakteryzowali jako „ponurą”. Przedstawiona w niej wizja amerykańskiego stylu życia na przedmieściach przypominała obraz ludzi dryfujących w „smutnym, szarym, wypełnionym śmiercią świecie”, jak ujęła to Joyce Carol Oates. Utwór ten stanowił rodzaj rozrachunku ze stanem amerykańskiego społeczeństwa lat 50. Filmowa adaptacja tekstu Yatesa dokonana przez Sama Mendesa w roku 2008 stanowi, jak się wydaje, nie tylko proste przeniesienie fabuły powieści na szklany ekran, ale również jest swego rodzaju próbą odkrycia w tym tekście uniwersalnych prawd na temat relacji małżeńskich oraz zależności człowiek - społeczeństwo.

Oba teksty kultury (zarówno film, jak i książka), ilustrujące tę samą opowieść, analizowane synchronicznie, ukazują pełne spektrum poruszanych $w$ tej fabule problemów. Lektura powieści daje odbiorcy możliwość poznania całej złożoności psychiki bohaterów, motywów i pobudek ich działań, opartych na indywidualnej historii życia (każdy kolejny rozdział powieści wprowadza nową postać i na zasadzie zestawienia ukazuje podobieństwa i różnice zachodzące między głównymi bohaterami: April i Frankiem, a innymi wymienionymi w tekście osobami). Film zaś, korzystając z właściwych sobie środków wyrazu, eksponuje i niezwykle sugestywnie ukazuje te elementy, które składają się na portret bohaterów jako członków określonej społeczności, uwikłanych w konkretne relacje, konwenanse. Wartościowa może okazać się zatem porównawcza analiza obu tych dzieł, zwana analizą komplementarną. Taki typ analizy zdaje się być uprawniony, biorąc pod uwagę spory teoretyczne i metodologiczne narosłe wokół problematyki filmowych adaptacji utworu literackiego i zagadnień związanych z przekładem interse- 
miotycznym w ogóle. W artykule Modele adaptacji filmowej. Próba wprowadzenia w problematykę ${ }^{I}$ Alicja Helman zadaje pytanie, czy adaptacja jako swego rodzaju tłumaczenie na inny język (wyrazu) dzieła literackiego jest w ogóle możliwa. Następnie, w toku analizy, badaczka stwierdza, iż nie istnieje model, w znaczeniu wzorca, typu idealnego, listy cech charakterystycznych, za pomocą którego można by opisać związki literatury i filmu. Film literatury nie adaptuje, a jedynie z niej korzysta. Zarówno zaś dzieła literackie, jak i dzieła filmowe, stanowią autonomiczne twory, przez wzgląd na odrębność systemów znaków, jakimi się posługują: literatura to system znaków językowych, film zaś - znaków audiowizualnych ${ }^{2}$. Opierając się na ustaleniach poczynionych przez Marylę Hopfinger ${ }^{3}$, Helman udowadnia, iż przekład intersemiotyczny jest zawsze częściowy, z uwagi na wyżej wspomniany brak odpowiedniości między znakami jednego i drugiego systemu. W dziele literackim da się wyznaczyć w tym kontekście trzy poziomy: budulcowy (całkowicie nieprzekładalny), budulcowo-znaczeniowy (przekładalny częściowo) oraz znaczeniowo-kulturowy (zasadniczo przekładalny).

Pamiętając o jednej z najstarszych norm estetycznych, głoszącej, iż nie istnieje tożsamość wypowiedzi przy różnicy tworzyw, to właśnie ten trzeci poziom, znaczeniowo-kulturowy i jego odrębne sposoby artykułowania w tak odmiennych semiotycznie mediach, jak literatura i film, stają się przedmiotem komparatystycznych analiz w analizie komplementarnej. Jej celem jest poszukiwanie sensów naddanych, ogólnej wymowy dzieła, próba dotarcia do jak największej ilości możliwych znaczeń i dających się wywieść interpretacji. Takie stanowisko jawi się jako uprawnione nie tylko w obliczu wymienionych wyżej różnic, występujących pomiędzy obiema sztukami, lecz również, a może przede wszystkim, na podstawie istniejących między nimi podobieństw. Obie sztuki w sposób sobie właściwy operują bowiem podobnymi składnikami: fabułą, bohaterami, czasoprzestrzenią przedstawioną ruchem. Zdaniem Alicji Helman to właśnie te czynniki decydują o tym, że tak odmienne formy wypowiedzi często uchodzą za tożsame. Proponowany tu model analizy jest potrzebny szczególnie w takich, wymienionych przez Helman przypadkach, gdy sens filmu, będącego adaptacją, jest różny od sensu oryginału. Przyjrzenie się tego typu realizacjom stwarza pole do zbadania sposobów funkcjonowania środków wyrazu właściwych każdej ze sztuk, ich specyfiki, która oznacza dzieła tak odmienne znaczeniowo - pomimo wyjściowego podobieństwa fabuły, bohaterów, czasoprzestrzeni przedstawionej i ruchu.

Niniejszy tekst jest cząstką szerzej zakrojonych badań nad zagadnieniem analizy komplementarnej.

1 A. Helman, Modele adaptacji filmowej. Próba wprowadzenia w problematykę, [w:] „Kino” 1979, nr 6, s. 28-29. Artykuł dostępny również online: http://www.akademiapolskiegofilmu.pl/pl/historia-polskiegofilmu/artykuly/modele-adaptacji-filmowej-proba-wprowadzenia-w-problematyke/124

2 Por. A. Helman, Modele adaptacji filmowej. Próba wprowadzenia w problematykę, [w:] „Kino” 1979, nr 6, s. 28-29. Artykuł dostępny również online: http://www.akademiapolskiegofilmu.pl/pl/historiapolskiego-filmu/artykuly/modele-adaptacji-filmowej-proba-wprowadzenia-w-problematyke/124

3 Por. M. Hopfinger, Adaptacje filmowe utworów literackich. Problemy teorii i interpretacji. WrocławKraków- Gdańsk, 1974. 
Nie prezentuje on zatem całego spektrum problemów związanych z takim ujęciem analitycznym. Z pewnością jednak zwraca on uwagę na możliwość obrania takiej właśnie strategii badawczej. W odczuciu autorki analiza komplementarna, w odróżnieniu od systematycznie prowadzonej analizy komparatystycznej, analizującej synchronicznie kolejne poziomy zarówno dzieła literackiego, jak i dzieła filmowego, stwarza możliwość ograniczenia badań do wyboru najbardziej znaczących elementów bądź to różnicujących, bądź podobnych, ale razem tworzących dodatkową jakość znaczeniową. Taki obszar analizy można dowolnie poszerzać, w zależności od tego, co dany interpretator uzna za szczególnie istotne lub jaką ilość sensów dostrzeże w danym dziele.

Celem uporządkowania niniejszego wywodu wyróżnionych zostało kilka obszarów problemowych: 1. Rozwój relacji małżeńskiej głównych bohaterów 2. Relacja głównych bohaterów z innymi członkami społeczeństwa 3. Analiza tzw. „Scen stołowych” (wspólnych posiłków, które zamiast stać się sposobnością do zacieśnienia społecznych więzów, okazują się być zarzewiem konfliktów). Sceny te, jak w soczewce, ukazują różnice światopoglądowe członków owej społeczności. 4. Problem domu - pułapki 5. Motyw drogi, jako miejsca, na które główni bohaterowie uciekają z domu oraz jako klucza do zrozumienia całego filmu (także w kontekście tytułu).

Cała analiza, podzielona na wyżej wymienione akapity, zogniskowana zaś będzie wokół zagadnienia małżeńsko-rodzinnego i społeczno-obyczajowego uwikłania jednostek oraz relatywności pojęć norma/odstępstwo. Podstawę metodologiczną artykułu stanowią tezy zawarte w pracy Ericha Fromma Patologia normalności. Przyczynek do nauki o człowieku. Zarówno powieść, jak i jej ekranizacja, relacjonują wydarzenia mające miejsce w Ameryce lat 50., jednak problemy w niej poruszane okazują się być problemami uniwersalnymi, a zatem współcześnie (dzisiaj) również aktualnymi i godnymi refleksji.

\section{Patologiczna codzienność?}

W pracy Patologia codzienności. Przyczynek do nauki o człowieku Erich Fromm zastanawia się, czy człowiek żyjący we współczesnym społeczeństwie jest jeszcze zdrowy psychicznie. Badaniem zagadnienia zdrowia psychicznego Erich Fromm zajął się intensywnie na początku lat 50 . Celem, jaki postawił przed sobą badacz, było znalezienie wyczerpującej odpowiedzi na pytanie, co naprawdę sprzyja zdrowiu psychicznemu, a co staje się przyczyną choroby ${ }^{4}$. Badacz powiązał usilne dążenia kształtujące zachowania $\mathrm{z}$ warunkami gospodarczymi i społecznymi, formułując tezę, iż cechy charakteru powszechne w społeczeństwie mogą być pojmowane jako wynik procesu dostosowania się do danej sytuacji społeczno-ekonomicznej ${ }^{5}$. Dokonując analizy współczesnych metod produkcji i psychicznych metod przystosowania, z których korzysta się, by sprostać wymaganiom gospodarki, Fromm stwierdzil, iż od człowieka wymaga się postaw psychicznych i cech społecznych, które powodują u niego chorobę psychiczną. To, co pozwala na osią-

\footnotetext{
4 Por. R. Funk, Przedmowa, [w:] E. Fromm, E. Fromm, Patologia normalności. Przyczynek do nauki o człowieku, red. R. Funk, tłum., S. Baranowski, R. Palusiński, Kraków 2013, s. 3.

5 Tamże, s. 5.
} 
ganie rozlicznych sukcesów, okazuje się jednocześnie niekorzystne dla zdrowia psychicznego: „Fromm bada patologię normalności, ukazując skutki gospodarki rynkowej wywołujące w człowieku chorobę. W centrum tego cierpienia znajduje się niezdolność człowieka do pozostawania w kontakcie z rzeczywistością"6.

W swym dziele Fromm podejmuje się analizy następujących zagadnień: zdrowie psychiczne we współczesnym świecie, układ odniesienia i zaangażowanie we współczesnej kulturze, alienacja a problem życia społecznego, pojęcie zdrowia psychicznego. Podstawą metodologiczną niniejszego tekstu będą myśli wybrane z czterech wykładów dotyczących patologii normalności, wygłoszonych przez Fromma 26 i 28 stycznia oraz 2 i 4 lutego 1953 roku w New School of Social Research w Nowym Jorku. Szczegółowe ustalenia, których dokonuje autor Mieć czy być, zostaną wykorzystane w analizie powieści i filmu Droga do szczęścia.

\section{Rozwój relacji małżeńskiej głównych bohaterów}

W pierwszym ze swych wykładów, zatytułowanych Patologia normalności współczesnego człowieka, Erich Fromm (poza wykazaniem dwóch podejść do kwestii normalności: statystycznego i jakościowego), wyróżnia również dwa punkty widzenia owej normalności. Pierwszy z tych punktów to ujęcie zdrowia psychicznego $\mathrm{w}$ charakterze relatywistycznym, społecznym. Ujęcie to odpowiada stanowi umysłu typowemu dla większości społeczeństwa. Z tego punktu widzenia zdrowie psychiczne stanowi przystosowanie się do trybu życia istniejącego społeczeństwa, zupełnie niezależnie od tego, czy jako takie jest ono zdrowe czy szalone: liczy się tylko to, że dany człowiek jest do niego przystosowany $^{7}$. W przeciwieństwie do tego punktu widzenia istnieje też taki, który zakłada istnienie obiektywnie uzasadnionych ocen wartościujących niebędących sprawami upodobań czy wiary ${ }^{8}$. Doskonałą ilustracją sporu pomiędzy tymi dwoma punktami widzenia i próbą poszukiwania odpowiedzi na pytanie, co jest normą, a co patologią, są postawy głównych bohaterów powieści Yatesa: Franka i April Wheelerów, ich wzajemne interakcje i próby radzenia sobie z życiem.

Film Droga do szczęścia otwierają kadry przedstawiające obrazy kolorowego miasta, stwarzającego wiele szans samorozwoju dostępnych głównym bohaterom - młodym ludziom, pełnym ideałów. W początkowych scenach filmu ukazani są oni w trakcie zabawy na prywatce; zbliżenie kamery na twarze objętych wpół młodych ukazuje ich wzajemne przyciaganie. April zafascynowały we Franku marzenia o prowadzeniu niestandardowego życia, Franka niewątpliwy wdzięk, czar i jakiś wewnętrzny blask dziewczyny, bo jak pisze Georges Bataille w swej książce Erotyzm: „nawet jeśli wybieramy kobietę, którą wybrałaby większość ludzi, to przecież nie ze względu na jakąś jej obiektywną cechę, lecz dlatego, że coś w niej nieuchwytnego głęboko nas porusza" ${ }^{9}$. Wzajemna bliskość bohaterów

\footnotetext{
Tamże, s. 6.

7 Por. E. Fromm, Patologia normalności..., dz. cyt., s. 13.

8 Tamże, s. 15.

$9 \quad$ G. Bataille, Erotyzm, Gdańsk 1999, s. 31.
} 
ukazana w tej scenie jest bodaj jedyną taką w całym filmie. W dalszych jego minutach bohaterowie ukazywani są podczas wspólnych rozmów, zawsze w oddzieleniu: widzimy osobno jej sylwetkę, osobno jego postać. Taki układ postaci jest bardzo wymowny i wskazuje na brak jedności między obojgiem małżonków. Podobne rozdzielenie widoczne jest w scenie, w której po nieudanym przedstawieniu grupy teatralnej, do której należy April, kobieta wraz z mężem przemierza korytarz budynku, w którym miał miejsce występ. Ludzie, którzy winni być sobie najbliżsi i wspierać się w trudnych chwilach, miast w bliskości, idą obok siebie, w sporym oddaleniu. To właśnie gry przestrzenne i operowanie światłem staje się dla twórców filmu głównym środkiem, wyrażającym status relacji obojga małżonków. Wykorzystane tu plany bliskie, amerykańskie, wprowadzają efekt teatralności, mający w tym dziele szczególne znaczenie: wprowadzenie specyficznej emocjonalności oraz stworzenie obrazu wycinka życia pewnej społeczności.

W filmie, inaczej niż w powieści, nie zaprezentowano fragmentów retrospekcyjnych dotyczących dzieciństwa i wczesnej młodości głównych bohaterów. To spora strata, bowiem dowiadując się, że np. April wychowywała ciotka, a rodzice pojawiali się w jej życiu jedynie od święta lub że Frank od dzieciństwa był piętnowany i wyśmiewany przez kolegów, odbiorcy łatwiej byłoby zrozumieć motywy ich niejednokrotnie skomplikowanych działań.

Relacja małżeńska Wheelerów: April i Franka, jest dość burzliwa, a zarazem paradoksalnie typowa. To młodzi ludzie przed 30-ką, którzy ze względu na dzieci i konieczność utrzymania rodziny zrezygnowali ze swych marzeń o podróżach i życiu wbrew ustalonym przez społeczeństwo konsumpcyjne regułom. Frank pracuje w przedsiębiorstwie stanowiącym prototyp współczesnych korporacji, April zaś zajmuje się domem. Grywa także w przedstawieniach amatorskiego teatru, ale jej ostatni występ zakończył się fiaskiem. Małżonkowie, kiedyś tak żarliwie zafascynowani sobą, teraz nie znajdują płaszczyzny porozumienia. Sfrustrowana April wymyśla panaceum na rutynę dnia codziennego, jakim według niej okazać się może wyjazd do Paryża, w trakcie którego to ona przejmie obowiązek utrzymywania rodziny, a jej mąż zajmie się poszukiwaniem celu życiowego i realizowaniem własnych marzeń, straconych przed laty. Na drodze do ich szczęścia pojawia się jednak pewna przeszkoda - April zachodzi w kolejną, trzecią już ciążę. Taki obrót spraw krzyżuje ich plany i z dnia na dzień doprowadza ich relację do coraz to większej ruiny, aż do momentu, w którym April decyduje się na wykonanie samo-aborcji, w wyniku której umiera.

Frank jawi się jako człowiek pełen zranień, który usiłuje znaleźć złoty środek między swymi zamierzeniami a realiami, w których przyszło mu żyć. April z kolei to typowa puella aeterna ${ }^{10}$, bojąca się dorosłości, ciągle uciekająca w swe marzenia. Frank zdaje się

10 Por. m.in. Linda Schierse Leonard, The Wounded Woman: Healing the Father-Daughter Relationship. Chicago: Swallow Press, 1982.Susan Armstrong-Buck and Gael Hodgkins, Humboldt Journal of Social Relations, Vol. 10, No. 2, The Study of Women: New Challenges, New Directions (SPRING/SUMMER 1983), pp. 258-260. http://www.charaktery.eu/artykuly/Psychologia-dla-Ciebie/810/Dziewczynka-nawieczność/, http://edukacja.eneteia.pl/index.php?option=com_content\&view=article\&id=10:maaencyklopedia-psychologii-gbi\&catid=10:encyklopedie, http://www.deon.pl/inteligentne- 

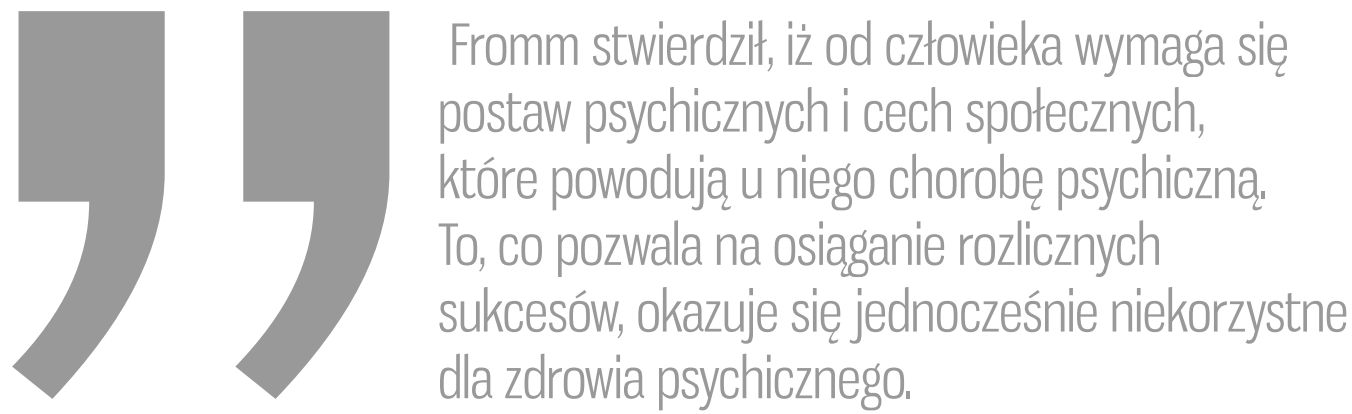

być gorącym zwolennikiem punktu widzenia gloryfikującego wagę przystosowania społecznego, nawet za cenę rezygnacji z własnych pragnień - bez refleksji nad pytaniem, czy podążanie za konformistycznym społeczeństwem jest w ogóle słuszne. April z kolei jawi się jako buntowniczka, nonkonformistka, usiłująca przeciwstawić się zastanemu porządkowi rzeczy. Podejmuje inicjatywy i snuje plany, nieprzypadające do gustu otaczającym ją ludziom. Jej powierzchownie niestandardowe pomysły na życie: podróże, poznawanie świata, realizowanie własnych marzeń, zamiast wykonywania nudnej, znienawidzonej pracy w imię budowania, wątpliwej w istocie, stabilizacji, są jednak próbą poszukiwania obiektywnych kryteriów normy i patologii. April staje się tu krytyczką czasów, w których przyszło jej żyć. Erich Fromm pisał, iż „choć nasze społeczeństwo posiada wiele dobrych cech, wiele takich, z których można być dumnym, jest rzeczą co najmniej wątpliwą, czy tryb życia, jakie obecnie prowadzimy bardziej sprzyja zdrowiu psychicz-

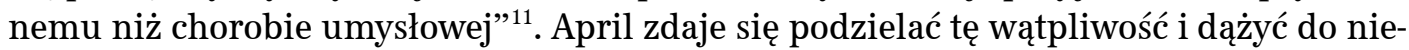
poddawania się presji otoczenia, którego postawy zostały poddane analizie w dalszych partiach tekstu.

\section{Relacja głównych bohaterów z innymi członkami społeczeństwa}

Powieść, w odróżnieniu od filmu, pozwala przyjrzeć się psychice bohaterów - zawiera bowiem bogate szkice osobowościowe, uwzględniające elementy historii życia, która tych bohaterów ukształtowała. Fabuła powieści, a w szczególności „Część druga”, została kompozycyjnie skonstruowana w taki sposób, iż każdy kolejny jej rozdział poświęcono nakreśleniu sylwetki odrębnego bohatera. Każda z tych postaci stanowi z kolei jakąś alternatywę/jakiś wariant konstruktu osobowościowego głównych bohaterów (żywi podobne tęsknoty, pragnienia, postępuje w myśl tych samych prawideł, pragnie kierować się tymi samymi ideałami); jednak z takich czy innych względów, w przeciwieństwie do Wheelerów, wszyscy oni dopasowali się do społeczno-obyczajowych realiów.

Pani Givings to stateczna, nieco wścibska starsza pani, zajmująca się sprzedażą nieruchomości. Najistotniejsze jest dla niej zachowanie pozorów i dbanie o umocnie-

zycie/psychologia-na-co-dzien/art,460,piotrus-pan-i-wieczna-dziewczynka.html

11

E. Fromm, Patologia normalności, dz. cyt., s. 18. 
nie swego pozytywnego wizerunku wśród ludzi. Shep i Milly Campbell to zaprzyjaźnieni sąsiedzi, którzy swe młodzieńcze ideały zatracili w rutynie dnia codziennego. Grube to sekretarka z firmy Franka, niezbyt lotna intelektualnie, ale tęskniąca za prawdziwym uczuciem, spokojem i życiowym komfortem. Wszystkie te postaci są jakiegoś rodzaju alter- ego Franka. Ich dążenia, status społeczny itd. są obrazem jego tęsknot, pragnień, marzeń, wewnętrznych dążeń. Fromm pisał, że „każde społeczeństwo posiada własny, uzasadniony interes dotyczący zgodności, interes z punktu widzenia przetrwania tego społeczeństwa, które musi zachować własną strukturę i indywidualność" ${ }^{12}$. Przedstawieni wyżej bohaterowie Drogi do szczęścia są reprezentantami dobrze zorganizowanego społeczeństwa, które dbając o swą wewnętrzną strukturę, każdemu z członków przypisuje odpowiednie role. Dlatego, być może, tak wielkie kontrowersje wśród przedstawicieli tego społeczeństwa wzbudza swoista rewolucyjność zachowań i poglądów małżeństwa Wheelerów, którzy w imię spełnienia swych marzeń gotowi są wyłamać się z ustalonych schematów. Najbardziej niezrozumiałą jest dla nich postawa April, Frank bowiem nieustannie balansuje na granicy społecznego przystosowania/ akomodacji a zrywu wolności.

Każda z wymienionych wyżej postaci jest więc jakoś społecznie dopasowana. Do tego grona nie przystaje jedynie John Givings - syn państwa Givings - genialny matematyk, który po próbie zamachu na życie swej matki, uznany za psychopatę, zostaje zamknięty w zakładzie psychiatrycznym. Postawa i sposób zachowania bohatera najbardziej zbliżone są do zachowań April. Głównym punktem wspólnym obojga bohaterów jest pragnienie przeciwstawienia się zastanym normom, walka z konwencjami, umiłowanie niezależności. Ich duchowe podobieństwo zostało przez twórców filmu wyeksponowane $\mathrm{w}$ warstwie wizualnej. Aby lepiej dostrzec te zbieżności, warto przywołać tu fragment Ikonologii Cesare Ripy, opisujący obraz szaleństwa:

„Mężczyzna w kwiecie wieku, ubrany w długą szatę barwy czarnej, roześmiany, jadący na kiju jak na koniu, w prawej ręce trzymający wiatraczek z papieru, miłą zabawkę i igraszkę dziecinną. Figura ta jest bardzo stosowna dla odwzorowania szaleństwa, boż przecie nie na czym innym polega wariactwo, mówiąc popularnie, tylko na wyczynianiu rzeczy nieprzystojnych i odbiegających od normalnych ludzkich obyczajów. O ile tedy mądrość społeczną zasadnie przypisujemy człekowi dojrzałemu, troszczącemu się o utrzymanie rodziny i dobro Rzeczpospolitej, to równie zasadnie Szaleństwem nazwiemy odrzucenie tych obowiązków, aby oddać się dziecinnym, zupełnie błahym zabawom. Wszystko to jest zgodne z opinią Horacego ( satyra 3, ks. 2)"13.

Niżej znajdujemy opis szaleństwa w „wersji kobiecej”:

\footnotetext{
Tamże, s. 16.

C. Ripa, Ikonologia, tłum. I. Kania, Kraków 2012, s. 375-376.
} 


\begin{abstract}
„Dziewczyna rozczochrana, bosa, z szyją opasaną niedźwiedzią skórą, ubrana w szatę mieniącą się różnobarwnie. W prawej dłoni trzyma zapaloną świecę, którą przybliża do słońca. Szaleństwo jest ogólnym określeniem wielkiej zmiany, jaka w ludzkich umysłach następuje skutkiem melancholii, gniewliwości, cierpienia, bądź trwogi, albo też wywołanej jakąś przyrodzona ułomnością. Maluje się je jako dziewczynę rozczochraną i bosą, bo szaleniec nie szanuje samego siebie ani innych i nie wie, co to takiego uprzejme obcowanie z innymi, gdyż nie zna jego wartości. Mieniący się kolor szaty oznacza niestałość właściwą szaleństwu. Niedźwiedzia skóra znaczy, że szaleńcem najczęściej rządzi gniew, stąd też widzimy, że niemal bez przerwy oddają się oni rozmaitym dziwactwom. W lewej dłoni trzyma blisko Słońca zapaloną świecę, gdyż zaiste znakiem szaleństwa jest przekonanie, iż wyraźniej się widzi przy słabym światełku niż w potężnym blasku Słońca" ${ }^{14}$.
\end{abstract}

Opis ten z powodzeniem mógłby stanowić słowną ilustrację kadrów przedstawiających Johna i April. To fizyczne podobieństwo postaci April - wiecznej marzycielki i Johna - szaleńca, skontrastowane z postaciami próbującymi nieustannie wpisać się w jakiś kanon, do których tak podobny jest Frank, ukazuje pewną ważką prawdę o wewnętrznych podziałach małżonków, ich sprzecznych celach i życiowych dążeniach.

$\mathrm{W}$ zestawieniu głównych bohaterów powieści z innymi ukazanymi w tym dziele postaciami, kluczowym problemem okazuje się być zagadnienie relatywności pojęć norma/patologia, zdrowie psychiczne/obłęd. Erich Fromm w swych dalszych rozważaniach stwierdza, że człowiek jest zdrowy psychicznie, jeśli może pełnić funkcje, jakie stawia przed nim społeczeństwo, jeśli może działać zgodnie z normami danego społeczeństwa" ${ }^{15}$. Następnie filozof przywołuje własną koncepcję zdrowia psychicznego, w myśl której jednostka zdrowa psychicznie jest zdolna do przezwyciężenia własnego narcyzmu, osiągnięcia miłości i obiektywizmu, przezwyciężania wyobcowania i uzyskania $\mathrm{w}$ ten sposób poczucia tożsamości i niezależności ${ }^{16}$. Fromm dopowiada, iż problem zdrowia psychicznego jednostki jest niepodzielnie związany z problemem zdrowia psychicznego społeczeństwa. W wykładzie drugim, zatytułowanym Pojęcie zdrowia psychicznego, Erich Fromm po raz kolejny prezentuje dwa opozycyjne pojęcia dotyczące analizowanego przez siebie zagadnienia „normalności”. Poza wspomnianą już definicją „zorientowaną na społeczeństwo", Fromm podaje także zgoła odmienne od niej, humanistyczne pojęcie zdrowia psychicznego: „Zdrowie psychiczne nie jest tutaj określone przez należyte funkcjonowanie w jakimś konkretnym społeczeństwie, ale przez kryteria właściwe dla samego człowieka”. Fromm pisze, iż „zawsze istniał konflikt między interesami indywidualnymi a interesami danego społeczeństwa i dlatego te dwa pojęcia zawsze były odmienne. Jednak rzeczywiście ci, którzy przedstawiają zorientowane na społeczeństwo pojęcie zdrowia psychicznego, zawsze czynią tak, jakby pojęcie to było tożsa-

14 E. Fromm, Patologia normalności, dz. cyt., s. 376 - 377.

15 Tamże, s. 86.

16 Tamże, s. 91. 
me z pojęciem zdrowia psychicznego zorientowanym na człowieka. Innymi słowy utrzymują oni, że to, co jest dobre dla konkretnego społeczeństwa, jest także dobre dla człowieka. I większość ludzi w to wierzy"17.

We wstępnych partiach niniejszego artykułu postawiono roboczą tezę, jakoby postawy Franka i April stanowiły ilustrację opozycji między relatywnym a obiektywnym punktem widzenia problemu normy i szaleństwa. Zdaje się, że w tym miejscu słuszne będzie uzupełnienie tamtych ustaleń. Po wprowadzeniu kolejnego opracowanego przez Fromma podziału na pojęcie zdrowia psychicznego społecznego i humanistycznego można stwierdzić, że postawy Franka i April są przykładami realizowania tych odmiennych pojęć. Rozbieżności między ich postawami i wzorcami zachowań są zatem w istocie nie sporem typu „prawda/ fałsz”, a raczej egzemplifikacją różnic wynikających z obrania odrębnych perspektyw: zorientowanej na społeczeństwo i zorientowanej na jednostkę. Jednoznaczne rozstrzygnięcie tego, kto $w$ świecie przedstawionym $w$ analizowanych tekstach kultury jest według założeń Fromma zdrowy psychicznie, a kto nie, byłoby zatem z pewnością kwestą złożoną. Co prawda dobrowolne poddawanie się dyktatowi społecznemu nie jest czynnikiem, który staje się gwarantem normalności, albowiem zachowanie struktury społecznej wymaga nieraz od jednostek zachowań przeciwnych ich naturze. Również jednak w zachowaniach Johna i April, poza motywami pozytywnymi, świadczącymi o wysokiej ,indywiduacji”, próbie uczynienia życia wartościowym, ciekawym, wyróżnić możemy także elementy destrukcyjne, a te wskazują, że nie są to jednostki w pełni zdrowe. Wyznacznikiem zdrowia psychicznego są bowiem dla Fromma trzy umiejętności: przezwyciężenia w sobie narcyzmu ${ }^{18}$, wyobcowania ${ }^{19}$, nekrofilii ${ }^{20}$. Cech tych nie posiadają niestety dwaj bohaterowie, których odbiorca skłonny byłby klasyfikować jako, paradoksalnie, normalnych, bo gotowych wyrwać się z utartych społecznych schematów. John i April, mimo że silnie zindywidualizowani i pełni wolności, nie są zdrowi psychicznie, bo mimo iż nieustannie „walczą” z zastanym porządkiem społecznym, nie podejmują walki ani z własnym narcyzmem, ani poczuciem wyobcowania, które bierze się z braku więzi społecznych i znudzenia życiem, ani z nekrofilią, rozumianą przez Fromma jako „perwersyjny twór, za pośrednictwem, którego [istota] niszczy, bo nie potrafi tworzyć" "J1 John niszczy swą rodzinę i relacje w niej panujące - przyczyną umieszczenia go w szpitalu psychiatrycznym była przemoc wobec matki. April niszczy swe relacje małżeńskie oraz swe macierzyństwo w sensie tak metaforycznym, jak i dosłownym, dokonując samo-aborcji. Tych dwoje bohaterów przeciwstawia się zastanemu porządkowi rzeczy; zauważają z obranej przez siebie perspektywy fałsz i obłudę tej im przeciwnej, jednak są oni w stanie jedynie ja negować, nie proponując żadnych konstruktywnych rozwiązań. Ich postawa, objawiająca się destrukcyjnym pragnieniem 
niszczenia, wynika z braku nadziei. A to właśnie brak nadziei jest zdaniem Fromma jednym z najgorszych objawów braku zdrowia psychicznego ${ }^{22}$.

\section{"Sceny stołowe"}

Wspólne biesiadowanie przy stole jest postrzegane w wielu kulturach jako moment jednoczący, integrujący ludzi, swego rodzaju ukonstytuowanie mikro-wspólnoty rodzinnej, przyjacielskiej. W książce Historii rodziny. Pokrewieństwo, dom, seksualność Jean-Luis Flandrin nazywa posiłek rodzinny wręcz ,jednym z najważniejszych elementów życia rodzinnego" ${ }^{23}$. W filmie Droga do szczęścia tzw. „sceny stołowe” są niezwykle istotne. Ukazują one bowiem rodzaj relacji wiążących Wheelerów z resztą społeczeństwa, a także może bardziej fakt, iż miast integrującej, pełnią one funkcję dezintegrującą.

Pierwsza „scena stołowa” to przyjacielska herbatka u sąsiadów Shepa i Milly. Usytuowanie bohaterów - dwie pary małżeńskie siedzą naprzeciw siebie - staje się tutaj obrazem istniejących między nimi radykalnych różnic w wyznawanych poglądach na temat kształtu rodziny i sposobów prowadzenia codziennego życia. Podczas tej wizyty April i Frank dostrzegają zdziwienie i zdezorientowanie na twarzach swoich sąsiadów, wywołane przedstawioną przez nich wizją przyszłości w Paryżu. Znajdujący się pomiędzy obiema parami stół nie stanowi zatem czynnika scalającego, a raczej jego zaprzeczenie. Staje się znakiem pewnego rozłamu, zapory.

Najbardziej wymowną ze „scen stołowych” wydaje się być scena obiadu, na który Wheelerowie zapraszają państwa Givings z ich synem Johnem. Niezwykle interesujące i bardzo bogate w znaczenia jest znów usytuowanie bohaterów przy stole oraz sposób ich filmowania. W scenie tej wykorzystano: plan amerykański - ujęcie twarzy i części korpusu, pozwalający na doskonałe śledzenie mimiki bohaterów, która staje się lustrem ich wewnętrznych przeżyć, niezwykle w tej scenie istotnych. April siedzi naprzeciwko państwa Givings, zaś Frank zajmuje miejsce po przeciwnej stronie Johna. Taki układ postaci staje się metaforą walki i skrzyżowania cech/ wartości, które reprezentują poszczególni bohaterowie. I tak umiłowanie ładu, porządku, rodzinnego ciepła (ale też spowitego woalem pozorów reprezentowanych przez państwa Givings), umieszczone zostaje naprzeciw marzeń, wolności, pragnienia samorealizacji, sukcesu, stanowiących kwintesencję dążeń Apil. Natomiast umieszczenie naprzeciw siebie Johan i Franka staje się tu obrazem odwiecznej walki wolności, niezależności, niepodporządkowywaniu się obowiązującym normom z konformizmem i życiem w roli trybika wielkiej machiny konsumpcjonizmu. Poza usytuowaniem przy stole, ważne jest także tło i przestrzeń ukazująca się za każdym z bohaterów. Za plecami państwa Givings i Johna są okna, zasłonięte firankami i zasłonkami, przez które padają nieśmiało promienie słońca, tworząc półcienie. Za plecami April widać piękną słoneczną przestrzeń z widoczną w oddali zielenią drzew. Niestety przestrzeń ta znajduje się za szybą i to w dodatku spowitą gęstą siatką

22 Tamże, s. 106.

23 J.-L. Flandrin, Historia rodziny. Pokrewieństwo, dom, seksualność, w dawnym społeczeństwie, tłum. A. Kuryś, Warszawa 2015, s. 138. 
framug, będących symbolem uwięzienia bohaterki zarówno w roli matki i żony, do której nie przywykła i z której za wszelka cenę pragnęłaby się uwolnić, jak i uwięzienia w karbach własnych wizji i wyobrażeń na temat samej siebie, którym ze względu na zewnętrzne ograniczenia nie jest w stanie sprostać. Jedynie za plecami Franka znajduje się inna przestrzeń - otwarty korytarz - przejście do kolejnego pomieszczenia; na tle tego korytarzyka, niestety, również widać małe, przesłonięte okno. Życie Franka w takim ujęciu interpretować należy jako nieustanną próbę wyrwania się z zastanych norm, balansowania pomiędzy koniecznością wpisywania się w utarte społeczne konwencje i schematy, a próbą wyzwolenia z nich.

Interesująca jest również scena ostatniego wspólnego śniadania małżonków. April, planująca aborcję, ukrywając swe plany przed mężem, przygotowuje mu śniadanie, podczas którego jest dla niego niezwykle miła, jawiąc się jako wzorowa żona i matka, opiekunka domowego ogniska. Tu również istotne jest usytuowanie postaci i gra świateł. Postać Franka, za którą znajduje się salon z kominkiem i zasłonięte okno, pozostaje w półmroku, natomiast postać April, usytuowana na tle kuchennych mebli i sprzętów, jest otoczona blaskiem. Jej twarz opromienia słońce, wpadające znów - co znaczące przez okratowane okna. Światłość ta staje się zatem rodzajem symbolu piękna i promienności właściwej opiekunce domowego ogniska - atrybutów i cech, które April potencjalnie mogłaby posiadać, gdyby tylko chciała i do nich ograniczyła swe pragnienia, ale także staje się zapowiedzią jej śmierci, zakończenia ziemskiej wędrówki. W scenach kolejnych jej postać ukazywana będzie bowiem na tle trupiobladej bieli ścian i framug.

Film wieńczy scena wizyty u Milly i Shepa nowych sąsiadów, którzy po śmierci April i związanej z tym wyprowadzce Franka, wynajęli dom Wheleerów. Scena ta jest pewną klamrą kompozycyjną całej historii Wheelerów. Jeszcze nie tak dawno siedzieli oni w tym samym salonie; przekonani o swej wyjątkowości, roztaczali świetlane wizje własnej przyszłości, śmiejąc się w duchu ze swych sąsiadów: Milly i Shepa i ich przyziemnych marzeń i rutyny życiowej. Natomiast teraz ich miejsce zajęli inni małżonkowie, być może tak samo pełni czczych ideałów, którzy być może podzielą los swych poprzedników. Natomiast ci zwyczajni, zanurzeni w codzienności, mocno stąpający po ziemi Campbellowie trwają przy sobie i przędą swój los, może bez spektakularnych sukcesów i wzlotów, ale w spokojnej i wolnej od nerwów atmosferze rodzinnego ciepła i bliskości.

Fromm pisze, iż „każdy człowiek powinien znać rozwiązanie problemu własnego istnienia" ${ }^{24}$ oraz, że jednym z najgorszych cierpień w życiu człowieka jest nuda, i że ludzie zrobią wszystko (...) żeby przed nią uciec, żeby ją ukryć”" ${ }^{25}$. To właśnie z obawy przed nudą, rutyną April planuje przeprowadzkę do Paryża i marzy o ciekawym życiu, niepodporządkowanym społecznemu dyktatowi. Życiu, w którym mogłaby zachować indywidualizm, a nie być jedynie trybikiem wielkiej społecznej machiny. Mieszkańcy Revolutionary Road, inaczej niż April, skrzętnie ukrywają swe prawdziwe emocje i odczucia, w imię zachowania społecznej struktury.

\footnotetext{
24 Fromm, dz. cyt., s. 23.

25 Tamże, s. 24.
} 


\title{
DOM i inne pułapki
}

„Dom symbolizuje bezpieczeństwo, trwałość, schronienie, gniazdo rodzinne” ${ }^{26}$. Donald Preziosi w artykule „Rekonstruując źródła sztuki”27, wspominając książkę Josepha Rykwerta Adam `s House in Paradise. The idea of the Primitive Hut in Architectural History, pisze o huppah - żydowskiej materiałowej konstrukcji, opartej na drewnianym stelażu, w której odbywa się wesele:

\begin{abstract}
„Z czegokolwiek była zrobiona, zdecydowanie nie służyła do ochrony przed warunkami zewnętrznymi. (...) Schronienie zapewniane przez huppah było jedynie symboliczne. (...) Dla pary skrywającej się w środku było zarówno obrazem ich złączonych ciał, jak i dowodem świata na ich związek"28.
\end{abstract}

Przywołany tutaj fragment dowodzi, jak olbrzymią rolę w budowaniu relacji małżeńskiej, stającej się początkiem rodziny, ma dom, której huppah jest prototypem. Sposób ukazywania domu w filmie Droga do szczęścia jest znaczący i mówi bardzo wiele o relacji między głównymi bohaterami; ich kondycji psychicznej i miejscu w społeczeństwie. „Uroczy mały domek ze ślicznym otoczeniem. Prosty, czyste linie, ładny ogród, idealny dla dzieci”"29. Tymi słowami pani Givings prezentuje młodym małżonkom ów dom. Jednak całe to piękno rzekomo wyróżniające ów budynek w krajobrazie „niezdarnych, piętrowych budynków w mdlących pastelowych kolorach i w dodatku strasznie drogich"30, widzianych na osiedlu, okazuje się tylko fasadowym urokiem, miejscem zmarnowanych szans. Jako taki staje się też doskonałym obrazem statusu relacji Franka i April: „Na widok domu, długiego mlecznego kształtu na tle ciemnych drzew i nieba, mimowolnie pomyślał o śmierci” - czytamy w powieści Yatesa ${ }^{31}$. Dla April przestrzeń domu, lub może lepiej cała relacja małżeńska, której dom staje się tu metonimią, jest rodzajem pułapki, potrzasku. Do takiej interpretacji zdaje się uprawniać sposób ukazywania postaci: ładnie ubrana kobieta zazwyczaj ukazywana jest na tle okna i choć za szybą świeci słońce, jej postać pozostaje w cieniu, a na jej sylwetce odbijają się kraty z firanek lub okiennic. Poza przestrzenią domu - uwięzienie bohaterów widoczne jest także w innych miejscach. Doskonale obrazuje to scena wspólnej jazdy małżonków samochodem po odbytej kłótni. Wnętrze samochodu ukazane zostaje na kształt klatki, w której główni bohaterowie, pełni emocji, wzajemnych pretensji i frustracji, zostali uwięzieni niby zwierzęta. Po wyjściu z domu Frank i April od razu kierują się w stronę domu i zamyka-

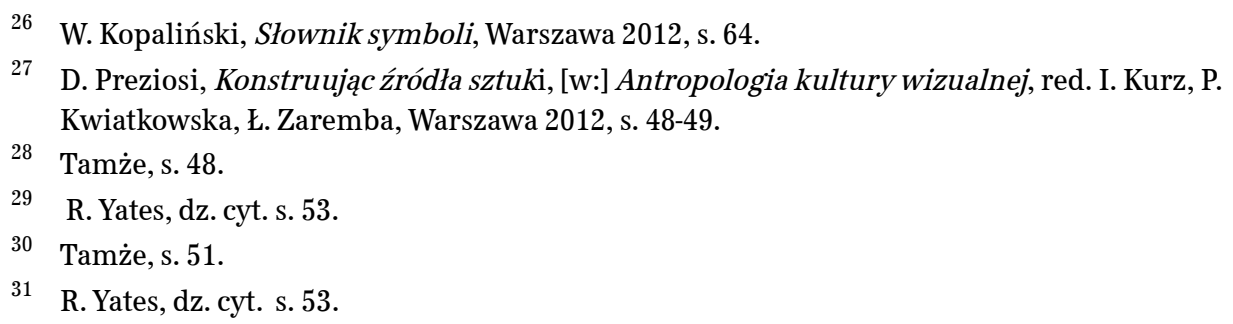




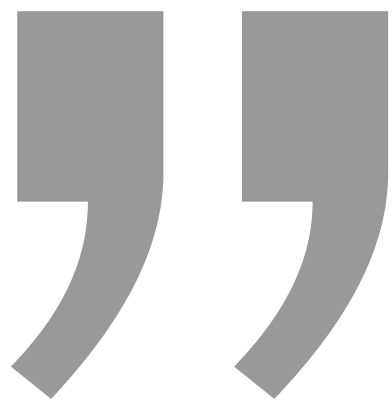

Motyw drogi, podobnie jak motyw domu, jest głęboko zakorzeniony w kulturze. Zazwyczaj „droga” staje się symbolem wędrówki, przemiany, zmiany. Revolutionary Road, a więc droga na cichym i spokojnym osiedlu, zamieszkiwanym przez przedstawicieli klasy średniej, staje się w tym filmie obrazem pewnych dążeń, marzeń bohaterów. Marzenia te, ze względu na swe odrealnienie, okazują się niemożliwe do ziszczenia i miast do rozwoju, przyczyniają się do klęski bohaterów.

ją za sobą drzwi. Zabieg ten ukazuje ich wzajemne zniewolenie sobą, niemożność znalezienia porozumienia i, co za tym idzie, uwolnienia się z tej patologicznej sytuacji, trwanie w atmosferze frustracji, wzajemnych oskarżeń.

Nie tylko April, ale również Frank znajduje się w swego rodzaju potrzasku. Dobitnie ukazuje to scena jego podróży do pracy. Pociąg, którym tam dojeżdża, jest rodzajem pułapki, a przynajmniej w taki sposób został on ukazany w filmie. W innym momencie sylwetka bohatera widnieje albo na tle całkowicie pustej przestrzeni (co staje się symbolicznym obrazem braku indywidualnego celu, poruszania się w rodzaju duchowej próżni), albo w tłumie całkowicie anonimowych osób, przypominających męskie persony w kapeluszach z obrazów Magritte’a. Ujęcie takie obrazuje samotność mężczyzny, a zarazem jego przeciętność, wpisywanie się w pewien model społecznej organizacji, w której pełniąc rolę głowy rodziny, pracuje, by utrzymać najbliższych. Droga Franka do pracy zilustrowana została w filmie jako nieustanne przemierzanie kolejnych klatek-pułapek: począwszy od domu przez wagon i dworzec, po samo biuro, zorganizowane tak, iż każdy z pracowników ma do swej dyspozycji niewielki skrawek przestrzeni, przywodzącej na myśl box przeznaczony dla zwierząt hodowlanych. W znanym tekście Gastona Bachelarda Dom rodzinny i dom oniryczny czytamy, iż: „Dom jest przeciw-światem, albo raczej światem-przeciw-ataków”"32 [miejscem, z którego] wynosi się pojęcie intymności”"33. Niestety, dom Wheelerów jawi się jako miejsce zupełnie niezgodne z postulatami Bachelarda: jako przestrzeń, w której nie tylko nie można schronić się przed atakami świata, lecz także miejsce, w którym wręcz pozyskać można nowe rany.

\footnotetext{
32 G. Bachelard, Dom rodzinny i dom oniryczny, [w:] tegoż, Wyobraźnia poetycka. Wybór pism, wyboru dokonał Henryk Chudak, tł. H. Chudak, Anna Tatarkiewicz; przedmowa Jan Błoński, Warszawa 1975, s. 316. 


\section{Motyw drogi : Revolutionary Road (Droga do szczęścia)}

Motyw drogi, podobnie jak motyw domu, jest głęboko zakorzeniony w kulturze. Zazwyczaj „droga” staje się symbolem wędrówki, przemiany, zmiany. Revolutionary Road, a więc droga na cichym i spokojnym osiedlu, zamieszkiwanym przez przedstawicieli klasy średniej, staje się w tym filmie obrazem pewnych dążeń, marzeń bohaterów. Marzenia te, ze względu na swe odrealnienie, okazują się niemożliwe do ziszczenia i miast do rozwoju, przyczyniają się do klęski bohaterów. Sam Yates przyznał w wywiadzie z roku 1974, że „chodziło mu o tytuł sugerujący, że rewolucyjna droga roku 1776 ... nasz najwspanialszy i najbardziej odważny duch rewolucyjny (być może przelotnie uosobiony przez April Wheeler) w latach pięćdziesiątych dotarł do czegoś w rodzaju ślepego zaułka"34.

Właśnie na drodze ma miejsce pierwsza kłótnia bohaterów, co odczytać można jako metaforę ich trwania w nieustannym poszukiwaniu statusu swej relacji, poszukiwania drogi tak do siebie nawzajem, jak i do samych siebie. Wymowna staje się scena, w której elegancko ubrana April w słoneczny dzień wynosi śmieci, patrząc tęsknie na pustą drogę, wspominając ich pierwszą wizytę w tym miejscu. Wtedy, przed laty, poszukiwali z Frankiem wymarzonego domu; w retrospektywnej scenie ilustrującej to wydarzenie najbardziej sugestywny jest, rysujący się na jej obliczu, wymuszony uśmiech, wyglądający tak, jakby próbowała przekonać samą siebie, że będzie tu szczęśliwa. Niestety autosugestia ma swe ograniczenia, o czym April boleśnie się przekonała. Bogata w znaczenia jest także jedna z ostatnich scen filmu, w której Frank po śmierci żony rozpaczliwie biegnie wzdłuż Revolutionary Road. Ujęcie to, wypełnione szarościami, na tle których sylwetka bohatera zdaje się rozmazywać, staje się tu wizualną metaforą poszukiwania samego siebie, próby podniesienia się po doznanej klęsce, poszukiwania nowej formuły własnej tożsamości.

\section{Misterium śmierci...}

W filmie bardzo wyraźnie wyeksponowano scenę śmierci bohaterki. Ciekawie ukazany został proces przygotowania się do czynu samo-aborcji, który stał się bezpośrednią przyczyną zgonu April. Przypominały one przygotowania poprzedzające rytualne ablucje czy sprawowanie kultów magicznych (April po kolei gotuje wodę, układa tkaniny...). Można by nawet pokusić się o porównanie owych scen z tymi, jakie ukazuje Nowosielski na swych malowidłach, wchodzących w skład cyklu Villa dei misteri. Obrazy te ukazują młodą niewiastę poddawaną rozlicznym katuszom fizycznym w celu osiągnięcia dojrzałości, uzdalniającej ją zawarcia małżeństwa. W filmie April po dokonaniu aborcji schodzi powoli do salonu z łazienki na piętrze. Na dywanie pojawia się kałuża krwi, cieknącej strużką z jej dróg rodnych. Cała spódnica nasiąka krwią. Scena ta jest bardzo sugestywna i wymowna. Krew, która jednoznacznie kojarzy się z życiem, cierpieniem czy męczeństwem, tutaj staje się sygnifikatem śmierci, pewnego unicestwienia życia, bez szans na odrodzenie. Motyw krwi jest, poza tym, szczególnie istotny w życiu bohaterki. Z lektury powieści Yatesa dowiadujemy się bowiem o pewnym incydencie z jej przeszłości:

34 R. Ford, Wstęp, [w:] R. Yates, Droga do szczęścia, dz. cyt., s. 14. 
„(...) większość wspomnień relacjonowała suchym tonem i trudno było nadać im sentymentalny charakter (,Zawsze wiedziałam, że nikomu na mnie nie zależy, i zawsze dawałam wszystkim do zrozumienia, że o tym wiem"), ale [w tym momencie przypomniał sobie] pewną opowieść o poranku w szkole Rye Country Day, kiedy miesięczne krwawienie niezwykle nagle i obficie zaskoczyło ją w środku lekcji”. Na początku tylko siedziałam - mówiła. Głupio postąpiłam, a potem było za późno”. Frank domyślał się z jakim upokorzeniem wiązała się ta sytuacja. Jak April musiała pospiesznie wstać, uciekać z klasy, być może w biegu upuściła książki, które następnie zmuszona była podnosić, podczas gdy za nią , ciągnął się regularny ślad w postaci czerwonych kropek" ${ }^{35}$.

Fragmenty te ukazują wymownie, jak sporym trudem dla April było doświadczenie dojrzałości, kobiecości. W swym umyśle pozostawała ona bowiem wieczną dziewczynką, tęskniącą za swymi rodzicami. Los bohaterki przypomina pośrednio dzieje mitologicznej Medei, która z zemsty na mężu zabija swe własne dzieci. W szerszym ujęciu April jawi się jako kobieta wpisująca się we wzorzec bohatera tragicznego, który poprzez hamatrię - winę niezawinioną, polegającą na złym rozpoznaniu swej sytuacji - doznaje klęski. Hamatrią April, a przez nią także i jej męża - Franka, było złe rozpoznanie własnej sytuacji, przekonanie o własnej wyjątkowości i niepowtarzalności i niezgoda na uznanie siebie za zwyczajnych przedstawicieli amerykańskiego społeczeństwa.

\section{Zakończenie}

„Celem życia, który odpowiada naturze człowieka w ramach jego egzystencji, jest zdolność do miłości, do używania rozumu, obiektywizmu i pokory, zachowania wolnego od zniekształceń kontaktu ze światem zewnętrznym i wewnętrznym (...). Kontakt z rzeczywistością, pozbycie się fikcji, pokora i obiektywizm w postrzeganiu rzeczy takimi, jakie są, nie zaś rozprawianie o rzeczach, które odrywają nas od rzeczywistości - to zasadnicza podstawa poczucia bezpieczeństwa, poczucia własnego ja, bez konieczności stosowania jakiegokolwiek oparcia, które miałoby zastąpić nasze poczucie tożsamości”" ${ }^{36}$. Zarówno powieść Yatesa, jak i film Mendesa, opowiadające tę samą fabułę, ukazują obraz społeczeństwa chorego, w którym jednostki jawią się albo jako niewolnicy społecznego dyktatu, albo indywidualiści niemogący przezwyciężyć trzech największych zagrożeń: narcyzmu, wyobcowania i pędu ku wewnętrznej nekrofilii. Analiza zaprezentowanego zarówno w powieści, jak i filmie mikroświata, przeprowadzona w świetle Patologii normalności Fromma pokazuje, jak trudne jest zachowanie zdrowia psychicznego w świecie współczesnym. Mieszkańcy Revolutionary Road to przedstawiciele dwóch odmiennych „obozów”, jednak żadna z tych grup, jak stwierdzono to wyżej, nie może być uznana za zdrową, normalną.

\footnotetext{
35

E. Fromm, dz. cyt., s. 29.
} 


\section{BIBLIOGRAFIA}

Antropologia kultury wizualnej, red. Iwona Kurz, Paulina Kwiatkowska, Łukasz Zaremba, Warszawa 2012.

Armstrong-Buck S., Hodgkins G., Humboldt Journal of Social Relations, Vol. 10, No. 2, The Study of Women: New Challenges, New Directions (SPRING/SUMMER 1983).

Bachelard G., Wyobraźnia poetycka. Wybór pism, wyboru dokonał Henryk Chudak, tł. H. Chudak, Anna Tatarkiewicz; przedmowa Jan Błoński, Warszawa 1975.

Bataille G., Erotyzm, Gdańsk 1999.

Flandrin J.-L., Historia rodziny. Pokrewieństwo, dom, seksulaność w dawnym społeczeństwie, tłum. A. Kuryś, Warszawa 2015.

Fromm E. , Patologia normalności. Przyczynek do nauki o człowieku, red. R. Funk, tłum. S. Baranowski, R. Palusiński, Kraków 2013.

Helman A., Modele adaptacji filmowej. Próba wprowadzenia w problematykę, [w:] „Kino” 1979, nr 6.

Hopfinger M., Adaptacje filmowe utworów literackich. Problemy teorii i interpretacji. Wrocław- Kraków- Gdańsk, 1974.

Kopaliński W., Słownik symboli, Warszawa 2012.

Ripa C., Ikonologia, tłum. I . Kania, Kraków 2012.

Schierse L. L., The Wounded Woman: Healing the Father-Daughter Relationship, Chicago: Swallow Press, 1982.

Yates R., Droga do szczęścia, tłum. A. Siewior - Kuś, Katowice 2009.

http://www.charaktery.eu/artykuly/Psychologia-dlaCiebie/810/Dziewczynka-na-wieczność/

http://edukacja.eneteia.pl/index.php? option=com_content\&view=article\&id=10:maa-encyklopediapsychologii-gbi\&catid=10:encyklopedie,

http://www.deon.pl/inteligentne-zycie/psychologia-na-codzien/art,460,piotrus-pan-i-wieczna-dziewczynka.html

\section{O AUTORCE:}

Mgr Natalia Kotarba - Doktorantka Wydziału Polonistyki Uniwersytetu Jagiellońskiego, sp. Literaturoznawstwo. Absolwentka Międzywydziałowych Indywidualnych Studiów I stopnia Uniwersytetu Mikołaja Kopernika (licencjat: Wiedza o kulturze śródziemnomorskiej, Katedra Filologii Klasycznej UMK, licencjat: Kulturoznawstwo: Katedra Sztuk Audiowizualnych UMK), absolwentka Międzywydziałowych Indywidualnych Studiów Humanistycznych UJ kierunek wiodący: polonistyka - komparatystyka, doktorantka Wydziału Polonistyki UJ, stypendystka Ministra Nauki i Szkolnictwa Wyższego za wybitne osiagnięcia naukowe - grudzień $2013 \mathrm{r}$.

Kontakt:nn.ichtios@gmail.com 